capped with whitemineral trioxide aggregate, Braz Dent J 15, 104-8.

5. Pariokh $M$, Torabinejad $M$ (2010). Mineral trioxide aggregate: A comprehensive literature review-Part I: Chemical, physical and antibacterial properties. J Endod, 36, 16-27.

6. A. T. Gurcan, F. Seymen (2019). Clinical and radiographic evaluation of indirect pulp capping with three different materials. European Journal of paediatric dentistry, 20, 105 .
7. Vimi George George, et al (2015). MTA and calcium hydroxide in primary teeth, Journal of Indian Society of Pedodontics and Preventive Dentistry, 2, 33.

8. NavyaP.Menon et al. Clinical and radiographic comparison of indirect pulp treatment using light-cured calcium silicate and mineral trioxide aggregate in primary molars: A randomized clinical trial. Contemporary Clinical Dentistry, 475- 480.

\title{
MÔ TẢ THỰC TRANG VIÊM GAN VI RÚT B,C TRÊN BÊ̂NH NHÂN GHÉP THÂ̂N TẠI BỆNH VIỆN BẠCH MAI
}

\section{TÓM TẮT}

Mục tiêu: Mô tả đăc điểm viêm gan vi rút $B, C$, đánh giá chức năng thận và một số yếu tố liên quan ớ nhóm bệnh nhân viêm gan $B$, C sau ghép thận tại bênh viện Bach Mai. Đối tượng và phương pháp: Nghiên cứu hồi cứu và tiến cứu, mô tả, phân tích trên tất cả các bênh nhân được ghép thân tại bệnh viên Bạch Mai, so sánh giữa nhóm không viêm gan và viêm gan $B, C$. Kết quá: Trên 223 bênh nhân ghép thận tại bệnh viện Bạch Mai có 24 bệnh nhân viêm gan $B$, 22 bệnh nhân viêm gan $C_{1} 1$ bệnh nhân đồng nhiếm $B, C$ và không viêm gan vi rút có 176 bệnh nhân. Số năm ghép trung bình là $3,18 \pm 1,77$ năm. Về viêm gan B: tỷ lệ hiện mắc $11,2 \%$, tỷ lệ mới mắc $0,9 \%$, tỷ lệ tái hoạt động $36 \%$, không có trường hợp nào bùng phát. Về viêm gan C: tỷ lệ hiện mắc $10,3 \%$, tỷ lệ mới mắc $1,3 \%$, tỷ lệ bùng phát 4,3\%, không có trường hợp nào tái phát. Nhóm viêm gan B có ALT trung bình sau ghép đến 1 năm là $26,20 \pm 14,80 \mathrm{UI} / \mathrm{L} ; 3$ năm là $32,20 \pm 25,12$ UI/L; từ 5 năm trở lên là $41,40 \pm 20,80$ UI/L. Nhóm viêm gan C có ALT trung bình sau ghép đến 1 năm là 27,61士 28,38UI/L; 3 năm là $30,50 \pm$

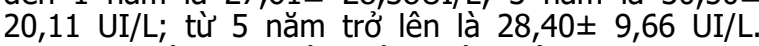
Creatinin máu trung bình của nhóm viêm gan $B, C$ sau ghép đến 1 năm là $103,89 \pm 27,96$ umol/l; 3 năm là $98,33 \pm 22,13$ umol/l; từ 5 năm trở lên là $100,90 \pm$ 25,35 umol/l. Tỷ lệ có protein niệu và có hông cầu niệu giống nhau là 29,8\%. Kết Luân: Tỷ lê mắc Viêm gan $B, C$ trong quẩn thể ghép thận tương đương tỷ lệ nhiễm viêm gan $B, C$ ở cộng đồng. Tỷ lệ tái hoạt động của viêm gan B tương đối cao $36 \%$. Men gan của nhóm viêm gan $\mathrm{B}$ cao hơn nhóm không viêm gan vi rút. Không có sự khác nhau về giá trị men gan giữa nhóm khống viểm gan vi rút và nhóm viêm gan C. Không có sự khác nhau giữa chức năng thận ở nhóm

${ }^{1}$ Trường Đại học Y Hà Nội

${ }^{2}$ Bênh viên Bach Mai,

${ }^{3}$ Bềnh viên Xanh Pôn

Chịu trách nhiệm chính: Lê Thị Thu Hằng

Email: lehangxanhpon2012@gmail.com

Ngày nhân bài: 10/7/2021

Ngày phản biên khoa hoc: 5/8/2021

Ngày duyệt bài: 25/8/2021

\section{Lê Thị Thu Hằng ${ }^{1,3}$, Đặng Thị Việt Hà ${ }^{1,2}$,} Đỗ Gia Tuyển ${ }^{1,2}$, Nguyễn Văn Dũng ${ }^{2}$

bệnh nhân không viêm gan vi rút và nhóm bệnh nhân viềm gan $B, C$ đến thời điểm 5 năm sau ghép. Tỷ lệ có protein niệu, hồng cầu niệu của 2 nhóm là như nhau.

Tư khóa: Ghép thận, Viêm gan B, Viêm gan C

\section{SUMMARY}

HEPATITIS B, C VIRUSES IN KEDNEY TRANSPLANT PATIENTS AT BACH MAI HOSPITAL

Objectives: To describe characteristics of hepatitis $B$ and $C$ viruses, to evaluate kidney function and some related factors in hepatitis $B$ and $C$ patients after kidney transplant at Bach Mai hospital. Subjects and methods: Retrospective and prospective studies, description and analysis on all kidney transplant patients at Bach Mai hospital, comparision between non-hepatitis and hepatitis $B$ and $C$ groups. Results: Out of 223 kidney transplant patients at Bach Mai hospital, there were 24 patients with hepatitis B, 22 patients with hepatitis $C, 1$ patient with hepatitis $B$ and $\mathrm{C}$ co-infection and 176 patients without viral hepatitis. The average number of years of grafting was $3.18 \pm$ 1.77years. Regarding hepatitis $\mathrm{B}$ : prevalence, incidence and reactivation rate was $11.2 \%, 0.9 \%$ and $36 \%$. No outbreak was detected. Regarding hepatitis C: prevalence, incidence and outbreak rate was $10.3 \%, 1.3 \%$ and $4.3 \%$, respectively. Recurrence was not detected. In hepatitis B patients, mean ALT after transplantation up to 1 year; 3 years and from 5 years or more was $26.20 \pm 14.80 \mathrm{UI} / \mathrm{L} ; 32.20 \pm 25.12 \mathrm{UI} / \mathrm{L}$ and $41.40 \pm 20.80 \mathrm{UI} / \mathrm{L}$, respectively. In hepatitis $\mathrm{C}$ mean ALT after transplantation up to 1 year; 3 years and from 5 years or more was $27.61 \pm 28.38 \mathrm{UI} / \mathrm{L}$; $30.50 \pm 20.11 \mathrm{UI} / \mathrm{L}$ and $28.40 \pm 9.66 \mathrm{UI} / \mathrm{L}$, respectively. Mean blood creatinine in hepatitis $B$ and $C$ patients after transplantation up to 1 year; 3 years and from 5 years or more was $103.89 \pm 27.96$ umol/l; $98.33 \pm$ $22.13 \mathrm{umol} / \mathrm{l}$ and $100.90 \pm 25.35 \mathrm{umol} / \mathrm{l}$, respectively. The rates of proteinuria and erythrocytosis were similar at $29.8 \%$. Conclusion: The prevalence of Hepatitis $B$ and $C$ in the kidney transplant population is equivalent to the rate of hepatitis $B$ and $C$ infection in the community. Hepatitis $\mathrm{B}$ reactivation rate is relatively high at $36 \%$. Concentrations of liver enzymes in hepatitis $B$ patients were higher than 
those in non-viral hepatitis patients. There was no difference in liver enzyme values between the nonviral hepatitis patients and hepatitis $C$ patients. There was no difference in renal function between non-viral hepatitis and hepatitis $B$ and $C$ patients at 5 years after transplantation. The rate of proteinuria and, erythrocytosis in 2 groups was not different.

Keywords: Kidney transplant, hepatitis B virus, hepatitis $\mathrm{C}$ virus.

\section{I. ĐĂT VẤN ĐỀ}

Ghép thận là một thành tựu y học hiên đại đã đem lại đời sống tốt đẹp hơn cho nhiều bệnh nhân suy thận mạn giai đoạn cuối trên toàn thế giới cũng như ở Việt Nam. Tuy nhiên, bệnh nhân ghép thận luôn luổn có những yếu tố bất lợi đe dọa cho sự ổn định của các chức năng thận ghép như tình trạng thải ghép, tác dụng phư của các thuốc ức chế miễn dịch, tình trạng nhiểm trùng, nhiễm vi rút.

Trong ghép thận nhiễm vi rút là một vấn đề quan trọng đối với điều trị. Thường gặp là nhiễm Cytomegalovirus $(\mathrm{CMV})_{\ell}$ Ebstein-Barr virus (EBV), BK virus, hoặc nhiếm vi rút viêm gan $B, C$ [1]. Ơ Việt Nam, tỷ lệ người mang HBV khá cao $12 \%$ [2]. Tại bệnh viện Chợ Rẫy tỷ lệ viêm gan $B$ trên bệnh nhân ghép thận là 5,54\% còn tại bệnh viện Việt Đức 9,8\% [3], [4]. Tỷ lệ nhiễm HCV ở miền Bắc thấp $(1$ - 2\%) nhưng miền Nam lại cao, có những nơi đến $10 \%$ [2]. Tại bệnh viện Chợ Rẫy tỷ lệ viêm gan $C$ trên bệnh nhân ghép thận là 7,72\%[3]. Ở bệnh viện Bạch Mai tính đến nay chưa có nghiên cứu nào. Vì vậy chúng tôi tiến hành nghiên cứu thực trang viêm gan vi rút $B, C$ ở bệnh nhân ghép thận tại bệnh viện Bạch Mai với mục tiêu 1). mô tả đặc điểm viêm gan vi rút $B, C$ và; 2$)$. đánh giá chức năng thận và một số yếu tố liên quan.

\section{II. ĐỐI TƯỢNG VÀ PHƯƠNG PHÁP NGHIÊN CỨU}

1. Đối tượng nghiên cứu. Tất cả người bệnh được ghép thận tại trung tâm thận- tiết niệu và lọc máu bệnh viện Bạch Mai. Tiêu chuẩn loại trừ đối tượng không hợp tác tham gia vào nghiên cứu và đối tượng ghép thận ở trung tâm khác.

2. Thời gian và địa điểm nghiên cứu. Nghiên cứu được tiến hành từ tháng 4/2020 7/2021 tại trung tâm thận- tiết niệu và lọc máu bệnh viện Bach Mai.

3. Thiết kế nghiên cứu. Nghiên cứu hôi cứu và tiến cứu, mô tả, phân tích.

Số liệu được thu thập vào bệnh án nghiên cứu mẫu được mã hóa, nhập, quản lý và xử lý trên phân mềm SPSS 16.0.

\section{KẾT QUẢ NGHIÊN CỨU}

3.1. Đặc điểm chung của nhóm nhiễm viêm gan $B, C$ trên bệnh nhân ghép thận

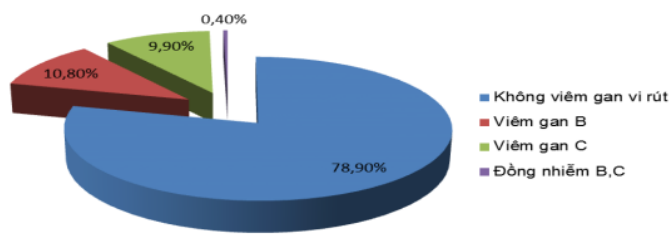

Biểu đồ 1. Tỷ lệ viêm gan B, C trong quẩn thể nghiên cứu

Nhân xét: Trong nghiên cứu này có $78,9 \%$ là không viêm gan vi rút. Tỷ lệ viêm gan $B$ đơn thuân và tỷ lệ viêm gan $\mathrm{C}$ đơn thuân tương đưỡng nhau lần lượt là: 10,8\% và 9,9\%. Đônng nhiếm viêm gan vi rút $B$ và $C$ là $0,4 \%$

Bảng 1. Số năm ghép

\begin{tabular}{|c|c|c|c|}
\hline Nhóm & Số BN & $\begin{array}{c}\text { Số năm } \\
\text { ghép }\end{array}$ & p \\
\hline Không nhiềm & 176 & $3,18 \pm 1,83$ & \multirow{2}{*}{0} \\
\cline { 1 - 3 } Nhiếm VG B, C & 47 & $3,19 \pm 1,57$ & 0,974 \\
\hline Chung & \multicolumn{2}{|c|}{$3,18 \pm 1,77$} & \\
\hline
\end{tabular}

Nhân xét: Số năm ghép trung bình của quẩn thể ghép thận là $3,18 \pm 1,77$ năm

3.2. Đặc điểm của viêm gan vi rút $B, C$ trên bệnh nhân ghép thận

Bảng 2. Tỷ lệ nhiểm viêm gan $B, C$

\begin{tabular}{|c|c|c|c|c|c|}
\hline Nhóm & $\begin{array}{c}\text { Mắc } \\
\text { trước } \\
\text { ghép } \\
\mathbf{( \% )}\end{array}$ & $\begin{array}{c}\text { Hiện } \\
\text { măc } \\
\mathbf{( \% )}\end{array}$ & $\begin{array}{c}\text { Mới } \\
\text { mắc } \\
\mathbf{( \% )}\end{array}$ & $\begin{array}{c}\text { Tái hoạt } \\
\text { động } \\
\text { hoắc tái } \\
\text { phát (\%) }\end{array}$ & $\begin{array}{c}\text { Bùng } \\
\text { phát } \\
(\%)\end{array}$ \\
\hline $\begin{array}{c}\text { Viêm } \\
\text { gan B }\end{array}$ & 10,3 & 11,2 & 0,9 & 36 & 0 \\
\hline $\begin{array}{c}\text { Viêm } \\
\text { gan C }\end{array}$ & 9,0 & 10,3 & 1,3 & 0 & 4,3 \\
\hline
\end{tabular}

Nhânn xét: -Viêm gan B: tỷ lệ hiện mắc $11,2 \%$, tỷ lệ mới mắc 0,9\%, tỷ lệ tái hoạt động viêm gan $B$ là $36 \%$, không có trường hợp nào bùng phát viêm gan $B$.

- Viêm gan C: tỷ lệ hiện mắc 10,3\%, tỷ lệ mới mắc $1,3 \%$, tỷ lệ bừng phát $4,3 \%$, không có trường hợp nào tái phát viêm gan $\mathrm{C}$.

Bảng 3. Chỉ số men gan của bệnh nhân viêm gan $B$ theo thơi gian

\begin{tabular}{|c|c|c|c|c|}
\hline \multicolumn{2}{|c|}{ Thời gian } & $\leq 1$ năm & $\mathbf{3}$ năm & $\geq$ 5năm \\
\hline \multirow{4}{*}{ ALT } & Không VG & 22,55 & 21,05 & 23,09 \\
vi rút & $\pm 13,35$ & $\pm 13,68$ & $\pm 13,42$ \\
& & $(n=148)$ & $(n=83)$ & $(n=33)$ \\
\cline { 2 - 5 } (UI/L) & Viêm gan B & 26,20 & 32,20 & 41,40 \\
& & $\pm 14,80$ & $\pm 25,12$ & $\pm 20,80$ \\
& & $(n=20)$ & $(n=15)$ & $(n=5)$ \\
\hline
\end{tabular}




\begin{tabular}{|c|c|c|c|c|}
\hline \multirow{2}{*}{ Chung } & $\begin{array}{c}22,99 \\
\pm 13,54 \\
(\mathrm{n}=168)\end{array}$ & $\begin{array}{c}22,76 \\
\pm 16,29 \\
(\mathrm{n}=98)\end{array}$ & $\begin{array}{c}25,50 \\
\pm 15,55 \\
(\mathrm{n}=38)\end{array}$ \\
\cline { 2 - 5 } & $\mathrm{p}$ & 0,298 & 0,097 & 0,028 \\
\hline
\end{tabular}

Nhận xét: Giá trị ALT trung bình của nhóm viêm gan $B$ tăng dần theo thời gian và đến thời điểm từ 5 năm sau ghép trở lên men gan nhóm viêm gan $B$ cao hơn nhóm không viêm gan vi rút có ý nghĩa thống kê với $\mathrm{p}<0,05$

Bảng 4. Chỉ số men gan của bệnh nhân viêm gan $C$ theo thờ gian

\begin{tabular}{|c|c|c|c|c|}
\hline \multicolumn{2}{|c|}{ Thời gian } & $\leq 1$ năm & 3 năm & $\geq 5$ năm \\
\hline \multirow{4}{*}{$\begin{array}{l}\text { ALT } \\
\text { (UI/L }\end{array}$} & $\begin{array}{l}\text { Không VG } \\
\text { vi rút }\end{array}$ & $\begin{array}{c}22,55 \\
\pm 13,35 \\
(n=148)\end{array}$ & $\begin{array}{c}21,05 \\
\pm 13,68 \\
(n=83)\end{array}$ & $\begin{array}{c}23,09 \\
\pm 13,42 \\
(n=33)\end{array}$ \\
\hline & ${ }_{C}^{\text {Viêm gan }}$ & $\begin{array}{c}33,50 \\
\pm 55,83 \\
(n=18)\end{array}$ & $\begin{array}{c}35,44 \\
\pm 53,91 \\
(n=16) \\
\end{array}$ & $\begin{array}{c}28,20 \\
\pm 11,82 \\
(n=5)\end{array}$ \\
\hline & Chung & $\begin{array}{c}23,74 \\
\pm 22,17 \\
(\mathrm{n}=166)\end{array}$ & $\begin{array}{c}23,37 \\
\pm 25,09 \\
(n=99) \\
\end{array}$ & $\begin{array}{c}23,76 \\
\pm 13,19 \\
(n=38)\end{array}$ \\
\hline & $P$ & 0,909 & 0,184 & 0,256 \\
\hline
\end{tabular}

Nhận xét: Nhóm không viêm gan và nhóm viêm gan C không có sự khác nhau về ALT có ý nghĩa thống kê với $p>0,05$

3.3. Đánh giá chức năng thân của nhóm bệnh nhân viêm gan $B$, $C$ theo thời gian ghép thận

Bảng 5. Chi số Creatinin máu theo thời gian ghép thận

\begin{tabular}{|c|c|c|c|}
\hline \multirow{2}{*}{ Nhóm } & \multicolumn{3}{|c|}{ Creatinin máu (umol/I) } \\
\cline { 2 - 4 } & $\mathbf{\leq 1}$ năm & $\mathbf{3}$ năm & $\mathbf{\geq ~ 5 ~ n a ̆ m ~}$ \\
\hline \multirow{2}{*}{ Không } & 110,31 & 101,94 & 96,7 \\
Nhiễm & $\pm 33,93$ & $\pm 33,72$ & $\pm 27,71$ \\
& $(\mathrm{n}=148)$ & $(\mathrm{n}=83)$ & $(\mathrm{n}=33)$ \\
\hline \multirow{3}{*}{ Nhiễm } & 103,89 & 98,33 & 100,90 \\
& $\pm 27,96$ & $\pm 22,13$ & $\pm 25,35$ \\
& $(\mathrm{n}=37)$ & $(\mathrm{n}=30)$ & $(\mathrm{n}=10)$ \\
\hline \multirow{3}{*}{ Chung } & 109,03 & 100,98 & 97,67 \\
& $\pm 32,85$ & $\pm 31,02$ & $\pm 26,94$ \\
& $(\mathrm{n}=185)$ & $(\mathrm{n}=113)$ & $(\mathrm{n}=43)$ \\
\hline $\mathrm{p}$ & 0,289 & 0,945 & 0,671 \\
\hline
\end{tabular}

Nhân xét: Creatinin máu trung bình từ sau khi ghép thận đến thời gian từ 5 năm trở lên ở nhóm không viêm gan vi rút và nhóm viêm gan $B$, C không có sự khác nhau có ý nghĩa thống kê với $p>0,05$.

3.4. Một số yếu tố liên quan đến chức năng thận ở nhóm bệnh nhân viêm gan $B$, C sau ghép thân

Bảng 6. Chỉ số ure máu, protein niệu, hồng cầu niệu

\begin{tabular}{|c|c|c|c|}
\hline Chỉ số & $\begin{array}{c}\text { Ure máu } \\
\text { (mmol/I) }\end{array}$ & $\begin{array}{c}\text { Protein } \\
\text { niệu (+) }\end{array}$ & $\begin{array}{c}\text { Hồng câu } \\
\text { niệu (+) }\end{array}$ \\
\hline Không & $6,24 \pm 2,37$ & $25,6 \%$ & $40,9 \%$ \\
\hline
\end{tabular}

\begin{tabular}{|c|c|c|c|}
\hline nhiêm & & & \\
\hline Nhiêm & $5,54 \pm 1,36$ & $29,8 \%$ & $29,8 \%$ \\
\hline Chung & $6,09 \pm 2,21$ & $26,5 \%$ & $38,6 \%$ \\
\hline p & 0,082 & 0,56 & 0,164 \\
\hline
\end{tabular}

Nhận xét: Ure máu trung bình của 2 nhóm khác nhau không có ý nghĩa thống kê với $p>0,05$. Tỷ lệ Protein niệu dương tính và tỷ lệ hồng cầu niệu dương tính giữa 2 nhóm không khác nhau có ý nghĩa thống kê với p> 0,05.

\section{BÀN LUÂN}

\section{1. Đặc điểm chung của viêm gan virus} B,C trên BN ghép thận. Trong quần thể ghép thận tại bệnh viện Bạch Mai tỷ lệ nhiễm viêm gan $B 11,2 \%$, tỷ lệ nhiễm viêm gan C $10,3 \%$ (bảng 2). Ớ Việt Nam, tỷ lệ người mang HBV khá cao 12\% [2]. Tỷ lệ viêm gan B ở bệnh viện Chợ Rẫy năm 2013 là 6,83\% [5]; ở bệnh viện Việt Đức năm 2016 là 9,8\%[4]. Tỷ lệ nhiễm HCV miền Nam Việt Nam cao, có những nơi đến $10 \%$ [2]. Tỷ lệ viêm gan $C$ ở bệnh viện Chợ Rẫy năm 2011 là $7,72 \%$ [3]; ở bệnh viện Việt Đức năm 2016 là 7,0\% [4]. Tỷ lệ viêm gan B, C trong nghiên cứu này tương đương với tỷ lệ nhiễm viêm gan B, C trong cộng đồng nhưng lại cao hơn so với bệnh viện Chợ Rẫy và bệnh viện Việt Đức có thể do sự khác biệt về chỉ định ghép thận những năm trước đây với những bệnh nhân suy thận có viêm gan $B, C$ thì chỉ định ghép thận còn hạn chế nhưng đến hiện nay do có sự ra đời của nhiều loại thuốc diệt vi rút an toàn và hiệu quả nên chỉ định ghép thận trên bệnh nhân viêm gan $B, C$ rất rộng rãi. Số năm ghép trung bình trong nghiên cứu này là $3,18 \pm 1,77$ và thời gian ghép lâu nhất là 9 năm. Kết quả này thấp hơn so với nghiên cứu tại Việt Đức năm $2016(5,45 \pm 3,78)$ [4].

4.2. Đặc điểm của viêm gan virus $B, C$ trên BN ghép thận. Trong nhóm 25 bệnh nhân viêm gan $B$ men gan không cao hơn giá trị bình thường phù hợp với số liệu tỷ lệ bùng phát viêm gan $\mathrm{B}$ là $0 \%$. So với nghiên cứu của Emori C.T và cộng sự năm 2014 theo dõi 140 bệnh nhân sau ghép có HBsAg dương tính thì có $25 \%$ bệnh nhân có biểu hiện bùng phát hoạt động của vi rút viêm gan $B$ trong $3,4 \pm 3$ năm sau ghép [6]. Theo Hồ Mạnh Linh nghiên cứu tại bệnh viện Việt Đức 2016 thì tỷ lệ bùng phát viêm gan $\mathrm{B}$ là $26,2 \%$ trong $5,9 \pm 3,9$ năm [4 ]. Trong nghiên cứu của chúng tôi tỷ lệ bùng phát viêm gan $\mathrm{B}$ là $0 \%$ thấp hơn nhiêu so với 2 nghiên cứu trên lý do có thể thời gian ghép thận trong nghiên cứu của chúng tôi chưa đủ dài $(3,18 \pm$ 1,77 năm) và có 43 trường hợp ghép trên 5 năm chúng tôi lại ko lấy được số liệu của những năm đầu sau ghép. Tuy nhiên tỷ lệ tái hoạt động viêm 
gan $\mathrm{B}$ trong nghiên cứu của chúng tôi lại khá cao $36 \%$. Tỷ lệ này cao hơn nghiên cứu của Trần Xuân Trường tại BV Chợ Rẫy năm 2013 với tỷ lệ viêm gan $B$ tái hoạt động sau ghép là 14,6\% [5]. Nguyên nhân là sau ghép thận, sử dụng các thuốc ức chế miễn dịch có thể làm vi rút nhân lên một cách tự do không kiểm soát vì vậy mà có thể làm HBV tái hoạt động và tái bùng phát sao chép. Bên cạnh đó có 3 trong số 9 bệnh nhân tái hoạt động viêm gan $B$ bỏ uống thuốc kháng vi rút một thời gian sau ghép là lý do khiến viêm gan $B$ tái hoạt động. Nhóm 23 bệnh nhân viêm gan $C$ có 1 trường hợp phát hiện nhiễm mới sau ghép thận 1 năm và có biểu hiện bùng phát viêm gan chiếm tỷ lệ 4,3\% với biểu hiện lâm sàng mệt mỏi, vàng da, xét nghiêm ALT tại thời điểm đó rất cao (253UI/L) cao hơn 5 lần giá trị bình thường cao. Không có trường hợp nào tái phát viêm gan $\mathrm{C}$. So với nghiên cứu của Trần Xuân Trường tại BV Chợ Rẫy 2011 thì tỷ lệ tái phát viêm gan C sau ghép lại rất cao $27,5 \%$. Điêu này có thể giải thích do tại thời điểm 2011 trở về trước bệnh nhân viêm gan $C$ chỉ có mỗi lựa chọn điều trị bằng interferon nên tỷ lệ đáp ứng vi rút hoàn toàn thấp hơn $(<50 \%)$, bây giờ điêu trị bằng thuốc uống DAAs tỷ lệ đáp ứng vi rút hoàn hoàn $>95 \%[7]$. Giá trị ALT trung bình của nhóm viêm gan $\mathrm{B}$ tăng dần theo thời gian $26,20 \pm 14,80 \quad U I / L * 32,20 \pm 25,12 U I / L *$ $41,40 \pm 20,80$ UI/L. Thời điểm từ 5 năm sau ghép trở lên men gan nhóm viêm gan $B$ cao hơn nhóm không viêm gan vi rút có ý nghĩa thống kê với $\mathrm{p}<$ 0,05 . Kết quả nghiên cứu này cũng tương tự kết quả nghiên cứu của Hồ Mạnh Linh tại bệnh viện Việt Đức (ALT* 30,9 \pm 11,0 UI/L) [4]. Nhóm viêm gan $C$ có ALT trung bình sau ghép đến 1 năm

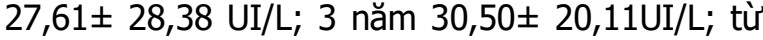
5 năm trở lên $28,40 \pm 9,66$ UI/L không có sự khác nhau so với nhóm không viêm gan vi rút có ý nghĩa thống kê với p> 0,05.

4.3. Chức năng thận của nhóm bệnh nhân viêm gan $B$, C sau ghép thận. Việc đánh giá chức năng thận ghép dựa vào chỉ số Creatinin máu. Trong nghiên cứu của chúng tôi creatinin máu trung bình từ sau ghép đến 1 năm ở nhóm không viêm gan vi rút và nhóm viêm gan $B, C$ lần lượt là: $110,31 \pm 33,93$ umol/l và $103,89 \pm 27,96$ umol/l, không có sự khác nhau giữa 2 nhóm tại thời điểm 1 năm với $P=0,289$. Creatinin máu trung bình chung cho cả 2 nhóm trong năm đầu là 109,03 \$ 32,85 umol/l tương tự với nghiên cứu của Hồ Mạnh Linh tại BV Việt Đức năm 2016 là 115,4 \pm 32,8umol/I[4]. Thời điểm 3 năm sau ghép thận thì nồng đô creatinin máu trung bình của 2 nhóm không nhiễm viêm gan vi rút và nhóm nhiễm viêm gan $\mathrm{B}, \mathrm{C}$ tương ứng là $101,94 \pm 33,72$ umol/l và $98,33 \pm 22,13$ umol/l khác nhau không có ý nghĩa thống kê với $\mathrm{P}=$ 0,945 . Nồng độ creatinin máu trung bình chung cho cả 2 nhóm là 100,98 $\pm 31,02$ umol/l. So với nghiên cứu này thì kết quả nghiên cứu nồng độ creatinin máu của chúng tôi thấp hơn nhiêu. Điều này chứng tỏ sự thành công của ghép thận tại bệnh viện Bạch Mai. Với thời gian lâu hơn từ 5 năm trở đi thì nồng độ creatinin máu trung bình của 2 nhóm không nhiễm và nhiễm viêm gan $B, C$ lần lượt là $96,7 \pm 27,71$ umol/l và $100,90 \pm 25,35 u m o l / l$, tuy rằng nồng độ creatinin máu của nhóm viêm gan $B, C$ có xu hướng tăng lên và cao hơn so với nhóm không viêm gan vi rút, nhưng không có ý nghĩa thống kê với $P=$ 0,671 . Điều này có thể là do cõ mẫu chưa đủ lớn và thời gian theo dõi sau ghép thận chưa đủ dài.

4.4. Các yếu tố liên quan đền chức năng thận ở nhóm viêm gan $B$, C sau ghép thận. Có protein niệu sau ghép dự báo giảm chức năng ghép lâu dài. Vì vậy chúng tôi tiến hành nghiên cứu xem việc nhiềm viêm gan $B, C$ ảnh hưởng như thế nào tới chức năng thận ghép thông qua nghiên cứu xem tỷ lệ protein niệu ở nhóm không viêm gan vi rút và nhóm nhiễm viêm gan $B, C$ có khác nhau không. Tỷ lệ có protein niệu ở nhóm không nhiễm viêm gan vi rút là $25,6 \%$ và nhóm nhiểm viêm gan $B, C$ là $29,8 \%$. Tỷ lệ này ở nhóm viêm gan $B, C$ nhìn thì cao hơn nhóm không nhiễm tuy nhiên sự khác nhau này không có ý nghĩa thống kê với $p=$ 0,56 . Tỷ lệ có Protein niệu trong nghiên cứu của chúng tôi ở cả 2 nhóm không nhiễm và nhiễm viêm gan $B, C$ đều cao hơn so với nghiên cứu của Hồ Mạnh Linh ở Việt đức là 9,8\% (nhóm không nhiễm) và $11,9 \%$ (nhóm nhiễm viêm gan $B$ ) [4].

\section{KẾT LUÂN}

1. Về đặc điểm viêm gan $B, C$ trên bệnh nhân ghép thận tại bệnh viện Bạch Mai:

- Tỷ lệ viêm gan $B$ đớn thuần là $10,8 \%$, tỷ lệ viêm gan $C$ đơn thuần là $9,9 \%$, đồng nhiễm viêm gan $B, C$ là $0,4 \%$.

- Tý lệ tái hoạt động viêm gan B là 36\%, tỷ lệ tái phát viêm gan $\mathrm{C}$ là $0 \%$

- Nhóm viêm gan B có giá trị ALT trung bình cao hơn nhóm không viêm gan vi rút.

- Nhóm viêm gan C không có sự khác nhau về giá trị men gan so với nhóm không viêm gan vi rút.

2. Về chức năng thận và một số yếu tố liên quan: Không có sự khác nhau giữa chức năng thận ở nhóm bệnh nhân không viêm gan vì rút và nhóm bệnh nhân viêm gan $B, C$ đến thời 
điểm 5 năm sau ghép. Các chỉ số Ure máu, protein niệu, hồng câuu niệu giữa 2 nhóm này không khác nhau.

\section{TÀI LIẸU THAM KHẢO}

1. Kotton C.N. và Fishman J.A. (2005). Viral Infection in the Renal Transplant Recipient. JASN, 16(6), 1758-1774.

2. Giáo trình bệnh truyên nhiễm Y5 Y HN.2009.

3. Trân Xuân Trường T.N.S. Kết quả theo dõi và điều trị sau ghép thận có nhiếm vi rút viêm gan $C$ tại bệnh viện Chợ Rẫy ( Kỷ yếu công trình ghép thận bệnh viện Chợ Rẫy 2011-2016).

4. Hồ Mạnh Lính. (2016). Nghiên cứu tình trạng nhiếm virus viêm gan $B$ ở bệnh nhân sau ghép

thận, 5-7, 11-13, 19-28.
5.Trân Xuân Trường T.N.S. Tình hình theo dõi và điêuu trị HBV sau ghép thận tại bệnh viện Chợ Rẫy (Kỷ yếu công trình ghép thẩn BV Chở Rẫy 2011-2016).

6. Emori C.T., Perez R.M., Matos C.A.L. de và cộng sự. (2014). Acute exacerbation of chronic hepatitis $B$ virus infection in renal transplant patients. Brazilian Journal of Infectious Diseases, 18(6), 625-630.

7. Cập nhật đîêu trị viêm gan C mạn-2019, <http:// vasld.com.vn/cap nhat-dieu-tri-viem-gan-c-man-2019>.

8. Sund S., Reisæter A.V., Fauchald P. và cộng sự. (1999). Living donor kidney transplants: a biopsy study 1 year after transplantation, compared with baseline changes and correlation to kidney function at 1 and 3 years. Nephrology Dialysis Transplantation, 14(10), 2445-2454.

\section{ĐẶC ĐIỂM GIẢI PHẪU LÂM SÀNG VẠT D.I.E.P TRONG TẠO HÌNH VÚ SAU CẮT BỎ TUYẾN VÚ DO UNG THƯ}

\section{TÓM TẮT}

Mục tiêu: Mô tả các đặc điểm giải phẫu lâm sàng vạt mạch xuyên động mạch thượng vị sâu dưới (D.I.E.P: Deep Inferior Epigastric Perforator Flap) trong tạo hình vú sau cắt bỏ toàn bộ tuyến vú do ung thư. Phương pháp nghiên cứu: Nighiên cứu mô tả trên 29 bệnh nhân được phẫu thuật tạo hình vú sử dụng vat D.I.E.P tại Bệnh viện Đại học Y Hà Nội từ 08/2019 tới 05/2021. Kết quả: Kích thước vạt phẫu tích trung bình dài $35,0 \pm 4,33 \mathrm{~cm}$, rộng $12,41 \pm 1,9$ $\mathrm{cm}$. Thể tích vạt phẩu tích trung bình 573,62 $\pm 130,39$ $\mathrm{ml}$, thể tích vạt sử dụng trung bình 408,97 $\pm 111,27$ ml (thấp nhất là $240 \mathrm{ml}$, lớn nhất là $750 \mathrm{ml}$ ). Thể tích vat sử dụng tạo hình lớn hơn thể tích vú cắt bỏ trung bình 10,02 $\pm 7,4 \%$. Số lượng mạch xuyên sử dung trung bình 1,97 $\pm 0,5$ mạch xuyên/ vạt. 100\% trường hợp vat có ít nhất 1 mạch xuyên lớn ở trong đường tròn bán kính $5 \mathrm{~cm}$ với tâm là rốn. Chiều dài cuống mạch trung bình là $8,95 \pm 1,69 \mathrm{~cm}$. Kết luân: Vạt D.I.E.P là chất liệu phù hợp và đáng tin cậy với những ưu điểm về giải phẩu hằng đinh, cuống mach dài và cấp máu an toàn, kích thước và thể tích vạt phù hợp với tao hình vú.

Từ khóa: Vạt mạch xuyên động mạch thượng vị sâu dưới, vạt D.I.E.P, tạo hình vú, giải phẩu lâm sàng.

\section{SUMMARY \\ CLINICAL ANATOMY OF D.I.E.P FLAP IN BREAST RECONSTRUCTION \AFTER TOTAL MASTECTOMY BY CÁCER}

*Trường Đại học Y Hà Nọi.

Chịu trách nhiệm chính: Phan Tuấn Nghĩa

Email: nghiapt@live.com

Ngày nhận bài: $11 / 7 / 2021$

Ngày phản biên khoa hoc: 14/8/2021

Ngày duyệt bài: 30/8/021
Objective: This paper aims to describe the clinical anatomical characteristics of the Deep Inferior Epigastric Perforator flap (D.I.E.P) in breast reconstruction after total mastectomy. Methods: The study was carried out on 29 patients at Hanoi Medical University hospital from August 2019 to May 2021. Results: the average flap size was $35,0 \pm 4,33 \mathrm{~cm}$ long and $12,41 \pm 1,9 \mathrm{~cm}$ wide. The average volume of dissected flap was $573,62 \pm 130,39 \mathrm{ml}$, the average volume of reconstruction flap was $408,97 \pm 111,27 \mathrm{ml}$ (the lowest was $240 \mathrm{ml}$, the highest was $750 \mathrm{ml}$ ). The flap used for reconstruction was 10,02 $\pm 7,4 \%$ larger than the removed breast volume. The average number of perforator used was $1,97 \pm 0,5$ perforator per flap, and the distance from the position of the perforator penetrating the superficial fascia of the abdomen to the umbilicus was $3,85 \pm 1,58 \mathrm{~cm}$. All cases have at least one large perforating vessel within a circle of radius $5 \mathrm{~cm}$ with center at the umbilicus. The average pedicle length was $8,95 \pm 1,69 \mathrm{~cm}$. Our conclusion once again emphasizes that the DIEP flap is a suitable and reliable material for the breast reconstruction.

Keywords. Deep inferior epigastric perforator flap, D.I.E.P flap, clinical anatomical characteristics.

\section{I. ĐĂTT VẤN ĐỀ}

Sử dụng chất liệu tự thân trong tạo hình vú là một trong những phương pháp được nhiều tác giả lựa chọn. Trong đó vạt D.I.E.P được các tác giả đồng thuận là lựa chọn hàng đầu để tạo hình vú sau cắt bỏ tuyến vú do ung thư với các ưu điểm là chất liệu tự thân, có khả năng chịu được quá trình hóa xa trị, tương đồng màu sắc, tính chất mềm mại đờng thời ít ảnh hưởng tới chức năng và cải thiện hình thể nơi cho vạt. Vạt D.I.E.P là vạt da cân mõ vùng thành bụng dưới, được cấp máu bởi các mạch xuyên da từ động 